\title{
The Antioxidant and Anti-Inflammatory Activities of 8-Hydroxydaidzein (8-HD) in Activated Macrophage-Like RAW264.7 Cells
}

\author{
Eunji Kim ${ }^{1,+}{ }^{\mathbb{D}}$, Young-Gyu Kang ${ }^{2,+}$, Ji Hye Kim ${ }^{1}$, Yong-Jin Kim ${ }^{2}$, Tae Ryong Lee ${ }^{2}$, \\ Jongsung Lee ${ }^{1, *(\mathbb{D}}$, Donghyun Kim ${ }^{2, *}$ and Jae Youl Cho ${ }^{1, *(\mathbb{D})}$ \\ 1 Department of Genetic Engineering, Sungkyunkwan University, Suwon 16419, Korea; \\ im144069@gmail.com (E.K.); kjhmlkhjml@hanmail.net (J.H.K.) \\ 2 Basic Research \& Innovation Division, R\&D Center, Amorepacific Corporation, Yongin 17074, Korea; \\ kangyg82@amorepacific.com (Y.-G.K.); jaykim@amorepacific.com (Y.-J.K.); trlee@amorepacific.com (T.R.L.) \\ * Correspondence: bioneer@skku.edu (J.L.); dhkim417@amorepacific.com (D.K.); \\ jaecho@skku.edu or jaecho67@gmail.com (J.Y.C.); Tel.: +82-31-290-7861 (J.L.); +82-31-280-5869 (D.K.); \\ +82-31-290-7868 (J.Y.C.) \\ + These authors contributed equally to this work.
}

Received: 27 May 2018; Accepted: 19 June 2018; Published: 21 June 2018

\begin{abstract}
Hydroxydaidzein (8-HD) is a daidzein metabolite isolated from soybeans. This compound has been studied for its anti-proliferation, depigmentation, and antioxidant activities. However, the anti-inflammatory activities of 8-HD are not well-understood. Through its antioxidant effects in ABTS and DPPH assays, 8-HD reduces the production of sodium nitroprusside (SNP)-induced radical oxygen species (ROS). By triggering various Toll-like receptors (TLRs), 8-HD suppresses the inflammatory mediator nitric oxide (NO) without cytotoxicity. We examined the regulatory mechanism of 8-HD in lipopolysaccharide (LPS)-induced conditions. We found that 8-HD diminishes inflammatory gene expression (e.g., inducible nitric oxide synthase (iNOS), cyclooxygenase (COX)-2, and tumor necrosis factor (TNF)- $\alpha$ ) by regulating the transcriptional activities of nuclear factor (NF)- $\mathrm{KB}$ and activator protein 1 (AP-1). To find the potential targets of 8-HD, signaling pathways were investigated by immunoblotting analyses. These analyses revealed that 8-HD inhibits the activation of TAK1 and that phosphorylated levels of downstream molecules decrease in sequence. Together, our results demonstrate the antioxidant and anti-inflammatory actions of 8-HD and suggest its potential use in cosmetics or anti-inflammatory drugs.
\end{abstract}

Keywords: 8-hydroxydaidzein; soybeans; antioxidant; anti-inflammation

\section{Introduction}

The human immune system comprises two arms: innate and adaptive immunity. Innate immunity is the first barrier faced by invading pathogens. It recognizes pattern-associated molecular patterns (PAMPs). Adaptive immunity removes pathogens in the late phases of infection and is accompanied by immunological memory [1,2]. PAMPs are recognized by specific pattern-recognition receptors (PRRs). These include the NOD-like receptors (NLRs), RIG-I-like receptors (RLRs), and Toll-like receptors (TLRs). In particular, TLRs recognize a wide range of PAMPs, including lipids, proteins, glycans, and nucleic acids. TLRs therefore serve a pivotal role in inflammation. Each TLR recognizes specific ligands [2,3].

When ligands bind to TLRs, inflammatory signaling pathways are activated via nuclear factor- $\mathrm{kB}(\mathrm{NF}-\mathrm{kB})$ and activator protein 1 (AP-1) [2,4]. Signals are transduced through adaptor molecules, including myeloid differentiation primary response 88 (MyD88) and TIR domain-containing 
adaptor-including interferon- $\beta$ (TRIF). These adaptors regulate the expression of diverse inflammatory genes [4-6]. NF- $\mathrm{kB}$ signaling induces IкB kinase (IKK) and IкB signal transduction. When signaled by TLRs, IKKs are activated to phosphorylate $I \kappa B$, which combines with inactive NF- $\kappa B$ [7]. Phosphorylated IкB is degraded by ubiquitination, and free NF- $\kappa B$ translocates to the nucleus to transcribe pro-inflammatory genes, like tumor necrosis factor (TNF)- $\alpha$, interleukin (IL)- $1 \beta$, cyclooxygenase (COX)-2, and inducible NOS (iNOS) [8-10]. In the AP-1 signaling pathway, signals transduce to IRAK and TAK1 by phosphorylation. These proteins associate with mitogen-activated protein kinases (MAPKs), which are known to be activated by TAK1 [2,10]. Activated MAPKs control the transcriptional activity of AP-1, thereby regulating inflammatory genes, such as MCP-1, IL-1 $\beta$, and TNF- $\alpha$ [11,12]. These inflammatory molecules play various roles in inflammatory responses.

Isoflavones are natural diphenolic compounds found in leguminous plants, such as kudzu vine, lupine, and soybean [13,14]. Soybean contains two major isoflavones: daidzein and genistein [15-17]. Both daidzein and genistein are biotransformed to monohydroxylated and dihydroxylated metabolites through cytochrome P450-dependent pathways [17]. 8-hydroxydaidzein (8-HD, Figure 1) is one daidzein metabolite isolated from fermented soybeans $[18,19]$. This compound has recently received attention due to its pharmaceutical and cosmetic effects [14]. Because of its bioactivity and rarity, researchers have sought various methods to produce 8-HD $[14,15,20]$. Though 8 -HD has shown activity relating to anti-proliferation, aldose reductase inhibition, depigmentation, and antioxidation, there have been no reports regarding its anti-inflammatory effects $[14,16,19,21]$. In this study, we investigated the anti-inflammatory and antioxidant activities of 8-HD and dissected underlying regulatory mechanisms.<smiles>O=c1c(-c2ccc(O)cc2)coc2c(O)c(O)ccc12</smiles>

Figure 1. Structure of 8-hydroxydaidzein (8-HD).

\section{Results}

\subsection{Antioxidant Effects of 8-HD}

We evaluated the antioxidant effects of 8 -HD using 2,2'-azino-bis(3-ethylbenzothiazoline6-sulphonic acid) diammonium salt (ABTS) and 2,2-diphenyl-1-picrylhydrazyl (DPPH) assays. In the ABTS assays, 8-HD cleared ABTS radicals, even at low concentrations (Figure 2a). In the DPPH assays, free radicals were scavenged in a dose-dependent manner (Figure $2 \mathrm{~b}$ ). The $\mathrm{IC}_{50}$ values for each experiment were $2.19 \mu \mathrm{M}$ and $58.93 \mu \mathrm{M}$, respectively. Additionally, we treated a keratinocyte cell line (HaCaT cells) with SNP, a NO-releasing reagent. We then examined the effect of 8-HD on NO production. 8-HD slightly decreased the amount of $\mathrm{NO}$ without affecting cell viability (Figure 2c,d). Figure 2 shows the antioxidant effects of 8-HD, both in cells and in cell-free systems. 


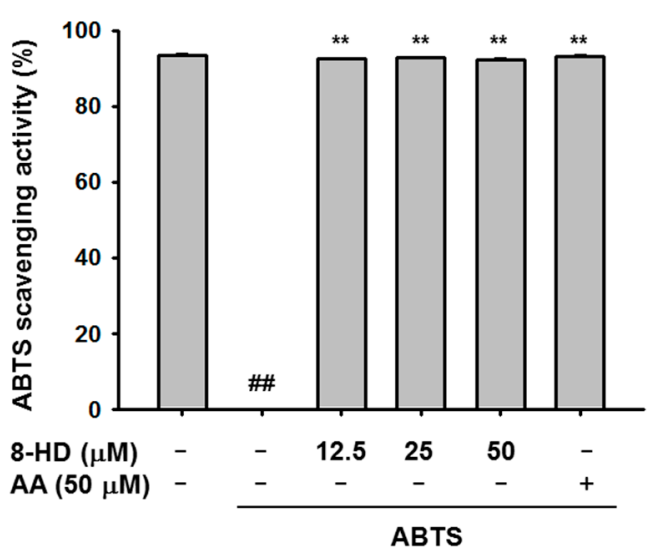

(a)

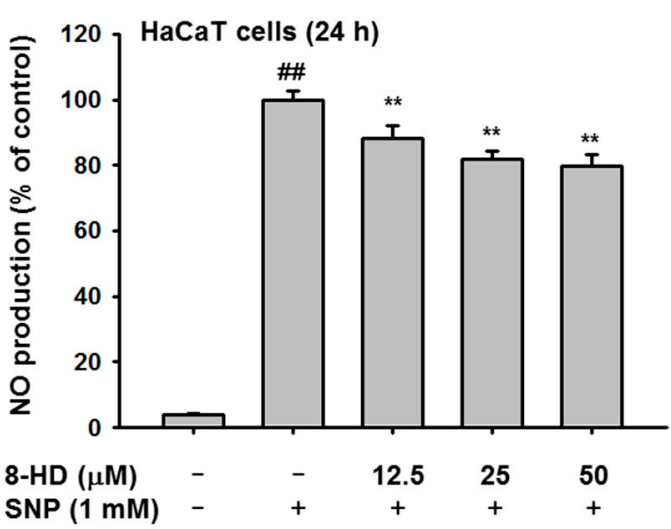

(c)

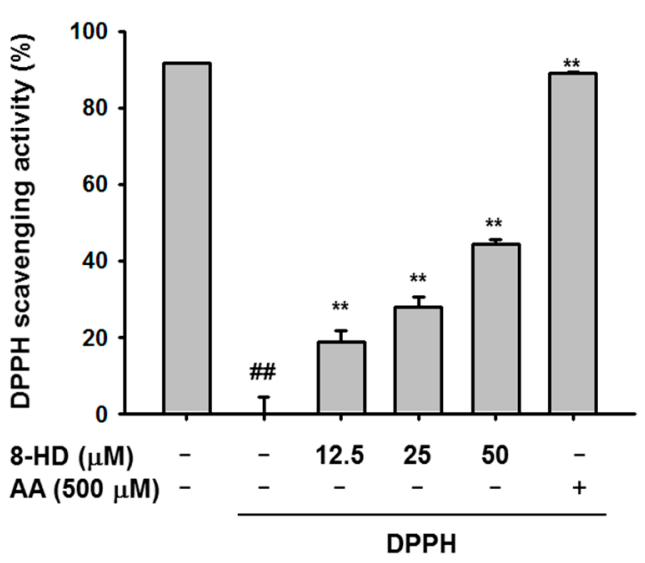

(b)

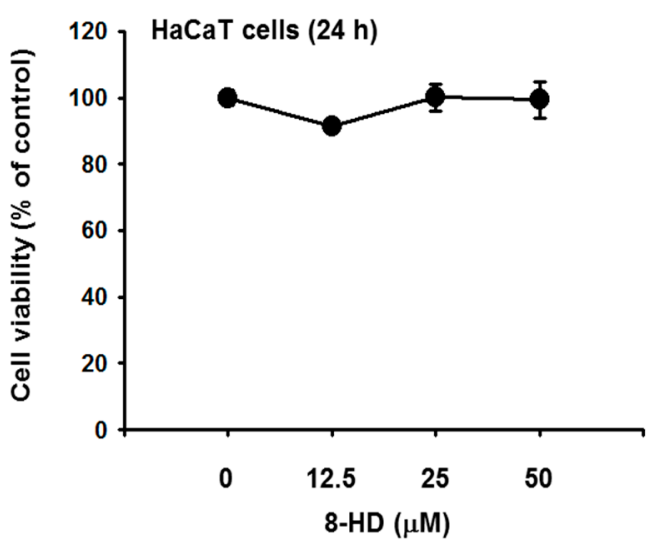

(d)

Figure 2. The antioxidant effects of 8-HD. (a) 8-HD was incubated with ABTS solution for $30 \mathrm{~min}$ at $37^{\circ} \mathrm{C}$. The absorbance was measured by spectrophotometry; (b) DPPH and 8-HD were mixed for $30 \mathrm{~min}$ at $37^{\circ} \mathrm{C}$. The absorbance at $517 \mathrm{~nm}$ was measured; (c) RAW264.7 cells were pre-treated with 8-HD for $30 \mathrm{~min}$ and then treated with SNP $(1 \mathrm{mM})$ for $24 \mathrm{~h}$. SNP-induced NO production was measured by Griess assays; (d) HaCaT cells were treated with 8-HD for $24 \mathrm{~h}$. Cell viability was examined by MTT assays; \#\# $p<0.01$ versus a normal group (untreated group); ${ }^{* *} p<0.01$ versus a control group (induced group); AA: ascorbic acid; SNP: sodium nitroprusside.

\subsection{Effect of 8-HD on Nitric Oxide Production}

Next, we investigated the immunomodulatory effects of 8-HD in a macrophage cell line (RAW264.7 cells). We induced RAW264.7 cells using different stimuli: lipopolysaccharide (LPS, a TLR4 inducer); polyinosinic-polycytidylic acid (poly[I:C], a TLR3 inducer); and peptidoglycan (PGN, a TLR2 inducer). 8-HD suppressed nitric oxide (NO) production without cytotoxicity when cells were stimulated by each inducer (Figure 3a,c). To increase the reliability of the NO assay, we used L-NAME as a positive control. L-NAME also decreased NO production without cytotoxicity (Figure $3 b, d$ ). These results suggest that 8-HD suppresses various TLR agonists. 


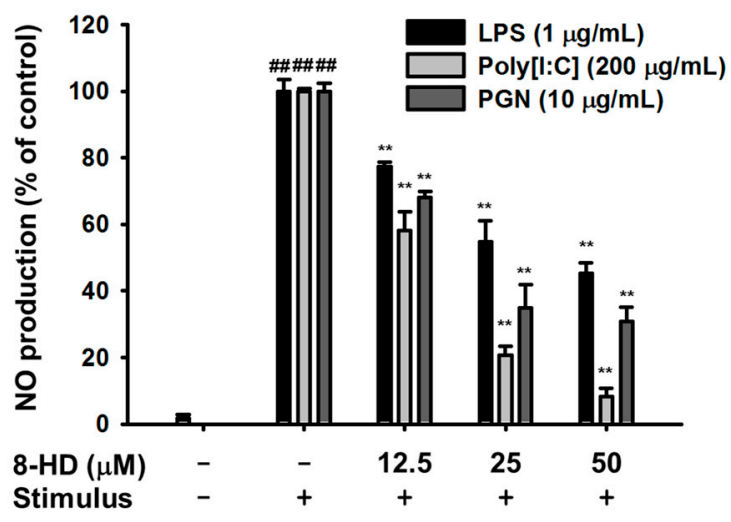

(a)

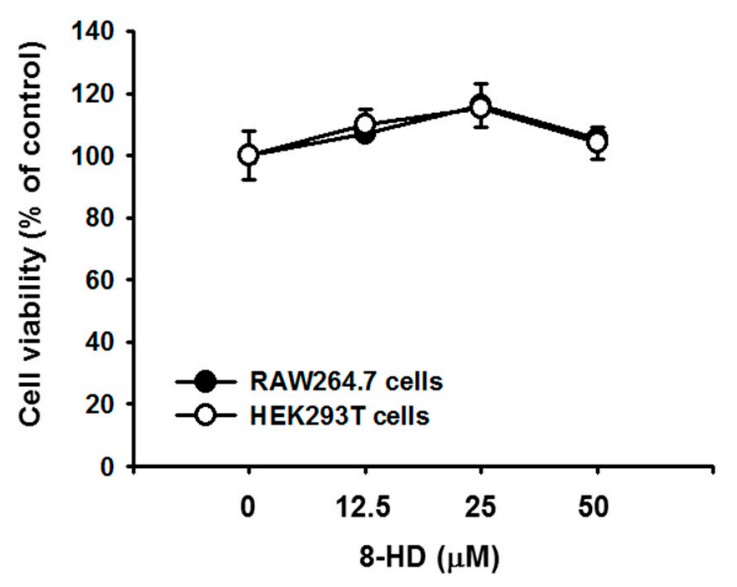

(c)

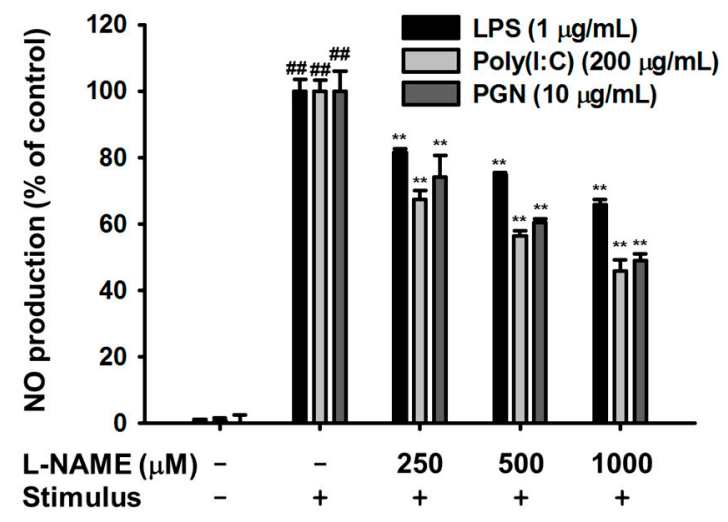

(b)

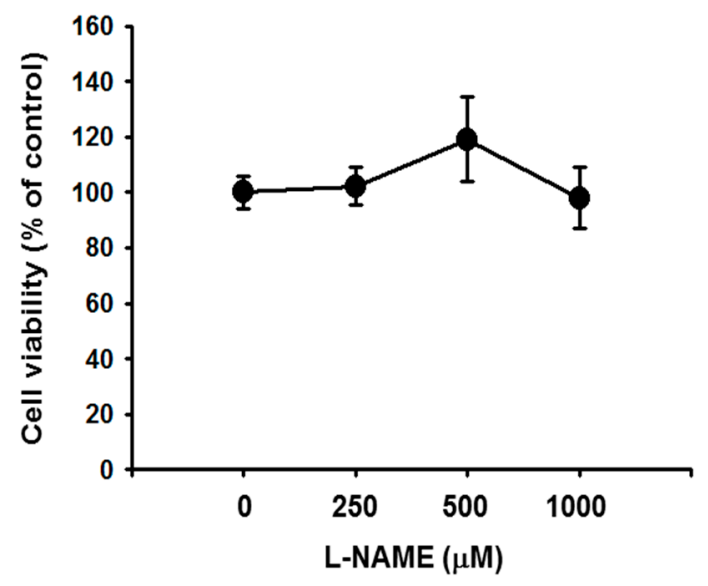

(d)

Figure 3. The anti-inflammatory effects of 8 -HD. $(\mathbf{a}, \mathbf{b})$ NO production levels for stimulus-treated RAW264.7 cells were determined by Griess assays. RAW264.7 cells were pre-treated with 8-HD $(0-50 \mu \mathrm{M})$ or L-NAME $(0-1000 \mu \mathrm{M})$ for $30 \mathrm{~min}$, and cells were then stimulated with Toll-like receptor immunoinducers (lipopolysaccharide (LPS), peptidoglycan (PGN), poly[I:C]) for $24 \mathrm{~h}$; (c,d) The cytotoxic effects of 8-HD and L-NAME on RAW264.7 and HEK293T cells were tested by MTT assay; \#\# $p<0.01$ versus a normal group (untreated group); ${ }^{* *} p<0.01$ versus a control group (induced group).

\subsection{Anti-Inflammatory Effects of 8-HD at the Transcriptional Level}

Figure 3 shows that 8-HD suppresses the inflammatory mediator production controlled by multiple TLR agonists. We deciphered the regulatory mechanism of 8 -HD in controlling TLR4-mediated inflammatory responses. To better understand the regulation of inflammation by 8-HD at the transcriptional level, we isolated mRNA and conducted semi-quantitative PCR to determine the presence of representative pro-inflammatory mediators (iNOS, COX-2, and TNF- $\alpha$ ). Under the LPS challenge, 8 -HD significantly reduced the expression of iNOS and TNF- $\alpha$; COX-2 was only slightly affected by 8-HD (Figure 4a). Next, we examined levels of phosphorylated, inflammation-related transcription factors over time. Phosphorylated transcription factors translocate to the nucleus [22-24]. Figure $4 \mathrm{~b}$ shows that phosphorylation of the NF-kB subunits (p65 and p50) was regulated by 8-HD at 15 and $30 \mathrm{~min}$, respectively. Regarding the AP-1 transcription factor, it was found that 8-HD can decrease the phosphorylation level of c-Fos but not c-Jun at $15 \mathrm{~min}$ (Figure 4c). These results suggest that 8-HD can regulate inflammation by suppressing the transcriptional activities of NF- $\mathrm{kB}$ and AP-1. 


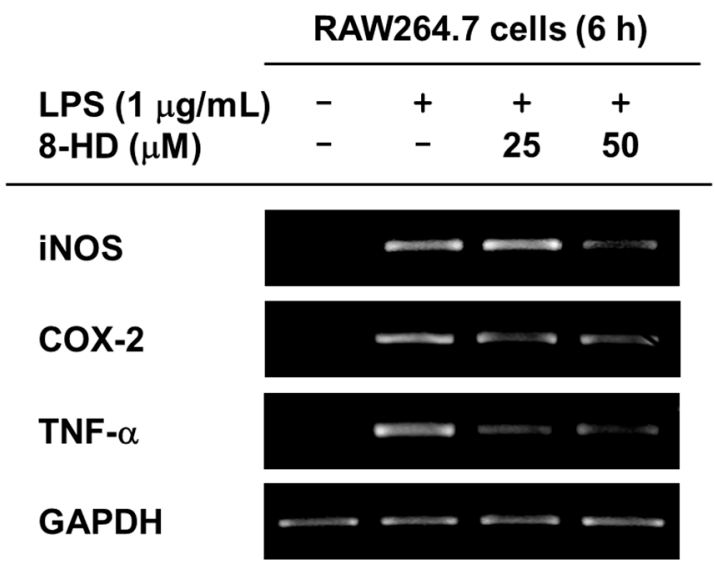

(a)
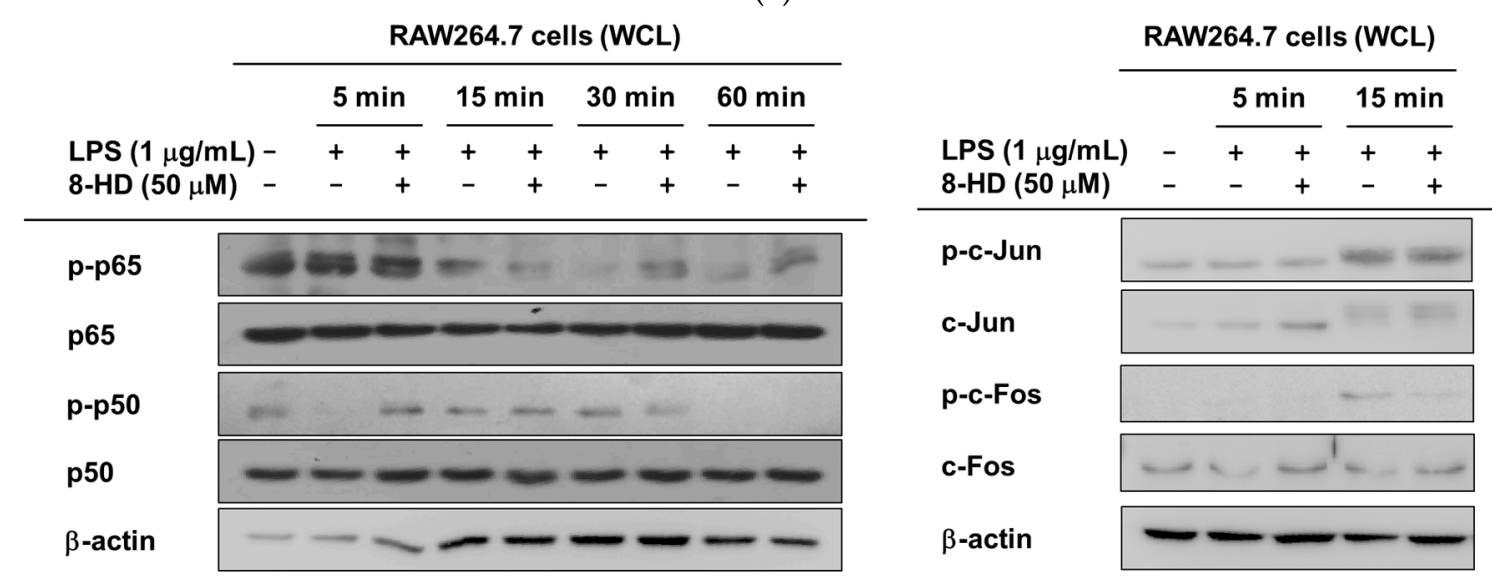

(b)

(c)

Figure 4. The regulatory mechanism of 8-HD at the transcriptional level. (a) The mRNA expression levels of inflammatory molecules were analyzed by semi-quantitative PCR. RAW264.7 cells were pre-treated with 8-HD for $30 \mathrm{~min}$, and LPS was added for $6 \mathrm{~h}$. mRNA was isolated, and RT-PCR was conducted; $(\mathbf{b}, \mathbf{c})$ RAW264.7 cells treated with 8-HD and/or LPS were analyzed in a time-dependent manner (0-60 min). The phosphorylation levels of p65, p50, c-Jun, and c-Fos were determined by immunoblotting. $\beta$-actin was detected as a loading control.

\subsection{Anti-Inflammatory Effects of 8-HD on NF- $\mathrm{KB}$ and AP-1 Signaling}

To investigate the way in which 8-HD inhibits NF-KB and AP-1 transcriptional activities, various signaling pathways were analyzed by immunoblotting. First, we assessed the NF- $\mathrm{kB}$ signaling molecules I $\mathrm{K} B \alpha$ and IKK $\alpha / \beta$, which are important for the nuclear translocation of NF- $\kappa B$ via the degradation of $I \kappa B \alpha$. Interestingly, the NF- $\kappa B$ inhibitory protein $I \kappa B \alpha$ was not regulated by $8-\mathrm{HD}$ (Figure 5a). This result indicates that 8-HD is not able to suppress the transcriptional activities of NF- $\mathrm{kB}$ (Figures $4 \mathrm{~b}$ and $5 \mathrm{a}$ ), due the absence of $\mathrm{I} \kappa \mathrm{B} \alpha$ degradation. For the AP-1 signaling pathway, however, 8-HD inhibited the activation of ERK and JNK at $5 \mathrm{~min}$ (Figure 5b). We therefore analyzed certain upstream molecules of ERK and JNK at earlier time points. The phosphorylated form of MEK1/2 was clearly decreased at 2 and $3 \mathrm{~min}$. 8-HD blocked the activity of MKK4 at $3 \mathrm{~min}$, and also blocked the activity of MKK7 at 2,3, and $5 \mathrm{~min}$. The activity of TAK1, a common upstream molecule of the MAPKKs, was also inhibited by 8 -HD (Figure 5c). 


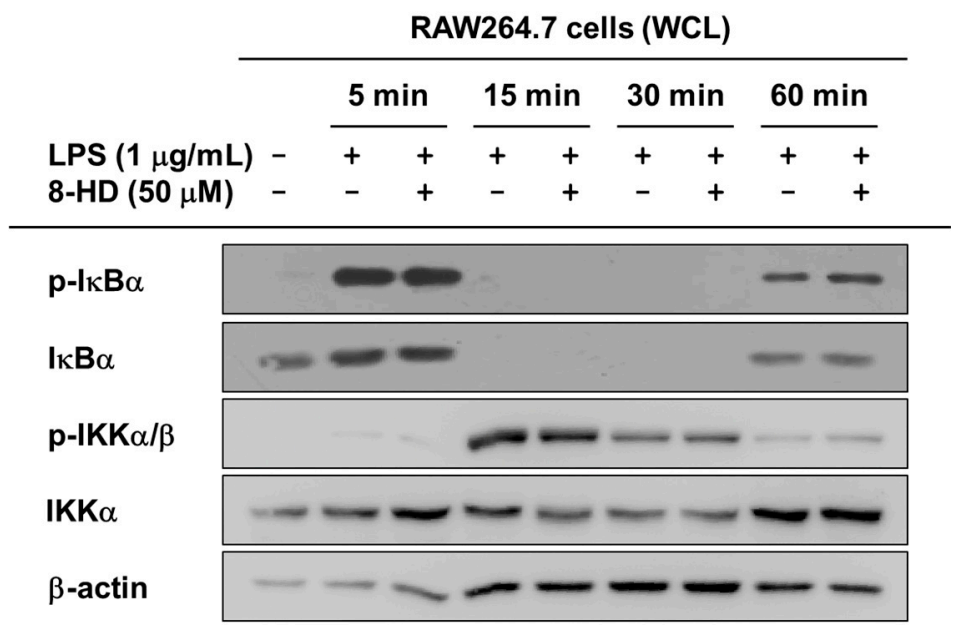

(a)

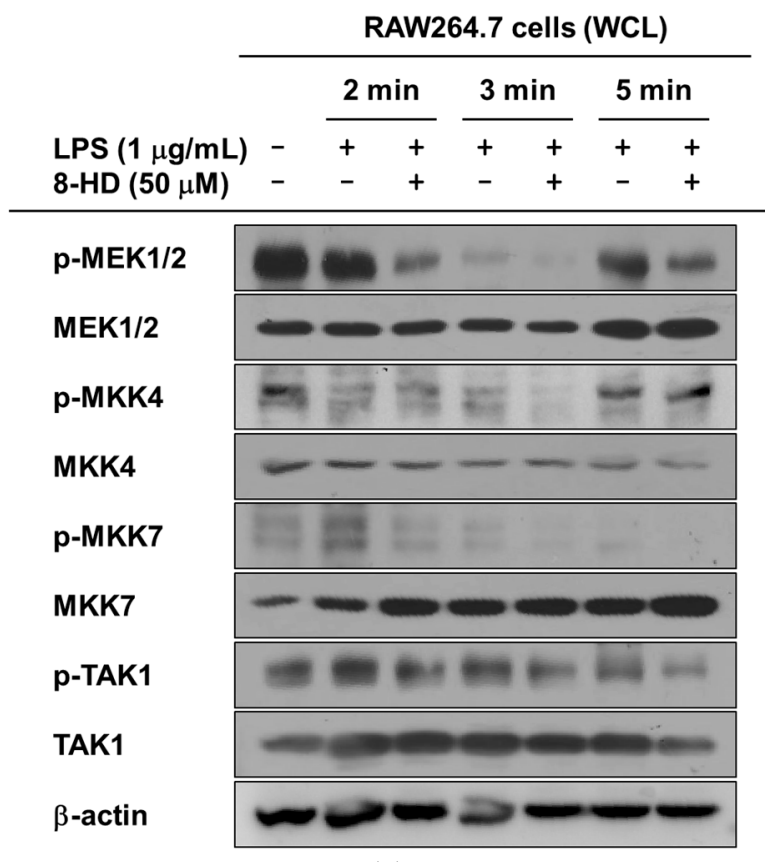

(c)

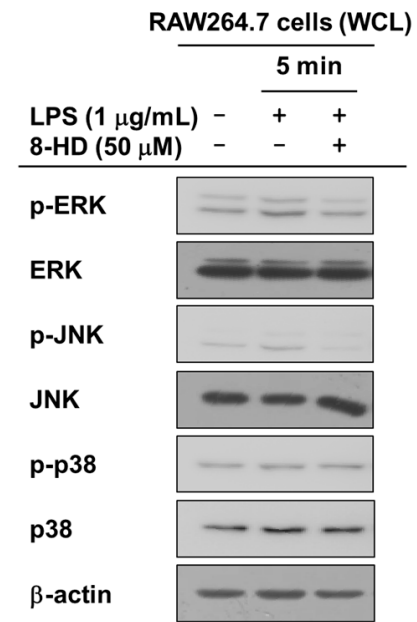

(b)

HEK239T cells (48 h)

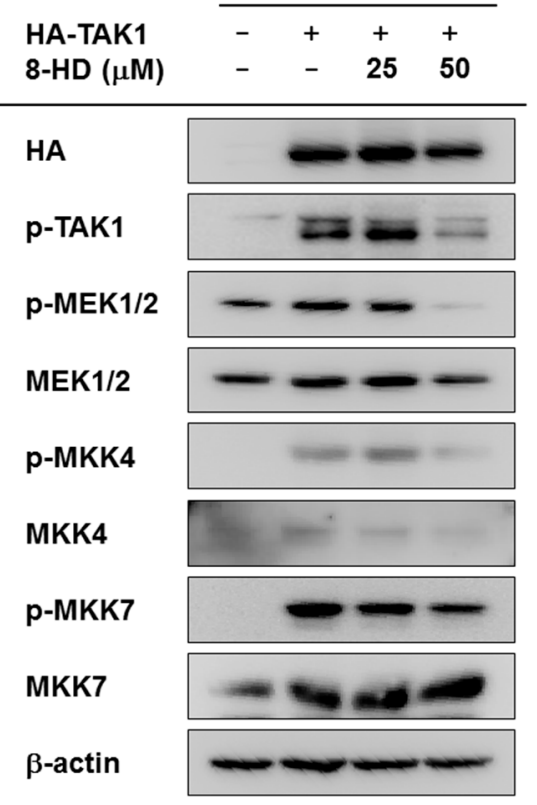

(d)

Figure 5. The effects of 8-HD on the NF- $\mathrm{KB}$ and AP-1 signaling pathways. (a) The effect of 8-HD on the NF- $\mathrm{KB}$ signaling pathway using LPS-treated RAW264.7 cell lysates. The phosphorylated forms of NF- $\mathrm{KB}$ inhibitory protein $(\mathrm{I} \kappa \mathrm{B} \alpha$ ) and IKK $\alpha / \beta$ were determined by immunoblotting; (b) The effect of 8-HD on the activator protein 1 (AP-1) signaling pathway using whole cell lysates. The phosphorylated levels of the mitogen-activated protein kinases (MAPKs; ERK, JNK, and p38) were measured by immunoblotting; (c) RAW264.7 cells were pre-treated with 8-HD for $30 \mathrm{~min}$, and LPS was then applied for different time points (2, 3, and $5 \mathrm{~min})$. The phosphorylated levels of MAPK/ERK kinase 1/2 (MEK1/2), mitogen-activated protein kinase kinase 4 (MKK4), MKK7, and transforming growth factor beta-activated kinase 1 (TAK1) were determined by immunoblotting; (d) HA-TAK1 was transfected into HEK293T cells for $24 \mathrm{~h}$. Cells were then incubated for $24 \mathrm{~h}$ in the presence or absence of 8-HD. Whole cell lysates were prepared, and immunoblotting was performed. The phosphorylation levels of TAK1, MEK1/2, MKK4, and MKK7 were verified. $\beta$-actin was detected as a loading control.

To confirm the inhibitory effect of 8-HD on TAK1, we transfected a TAK1 construct into HEK293T cells. We then screened for the downstream molecules MEK1/2, MKK4, and MKK7. Consistent with our previous results, the activities of MEK1/2, MKK4, and MKK7 were downregulated (Figure 5d). 
The immunoblotting results showed that 8-HD targets TAK1 and NF- $\mathrm{B}$. These findings imply that 8-HD regulates NF- $\mathrm{B}$ and AP-1 signaling during TLR4-induced inflammatory responses (Figure 6).

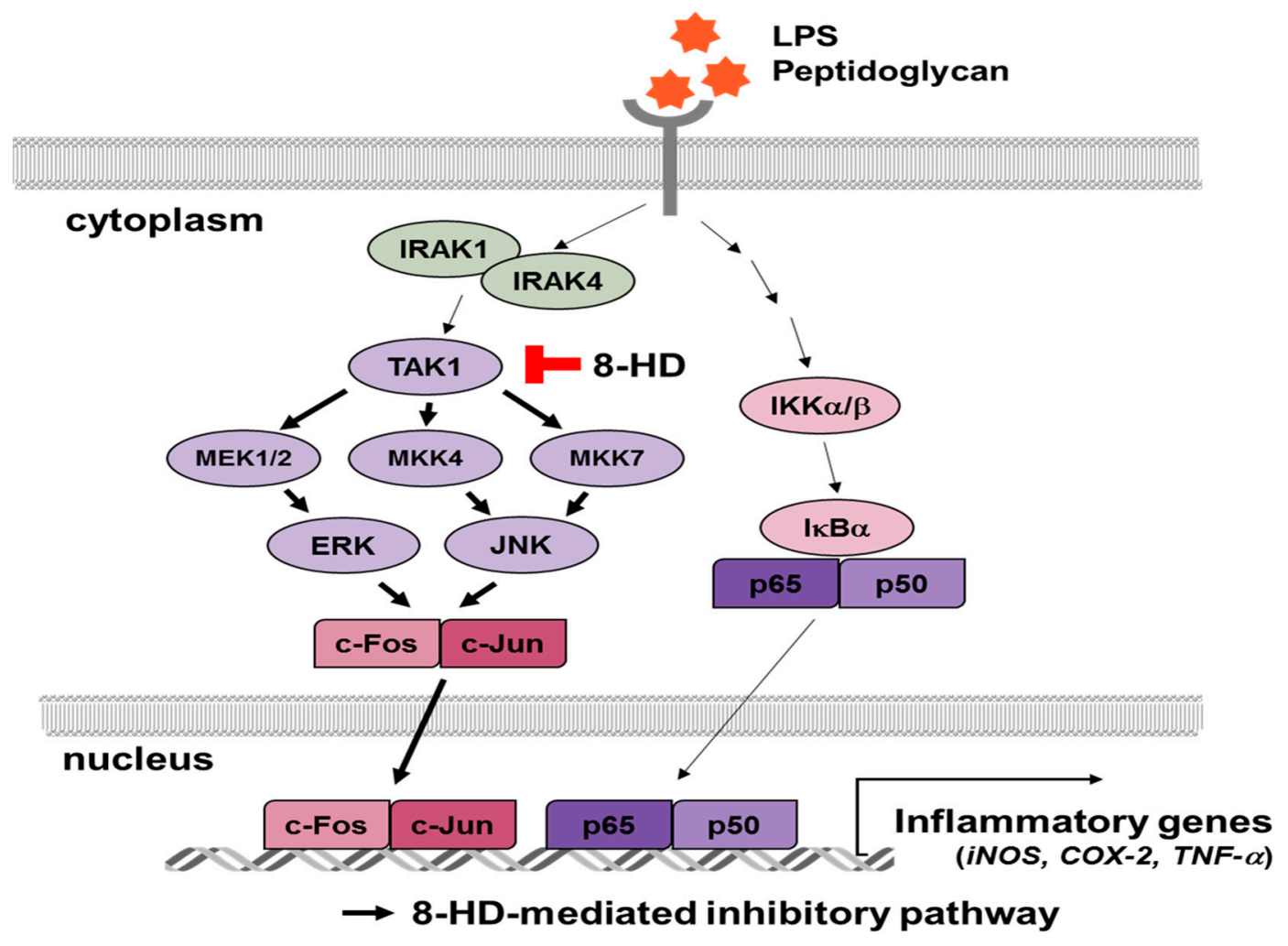

Figure 6. The regulatory effects of 8-HD on inflammatory signaling pathways. In the AP-1 signaling pathway, 8-HD suppresses the activity of TAK1, and subsequently, the transcriptional activity of c-Fos is also inhibited.

\section{Discussion}

8-HD is known to have antioxidant, anti-proliferation, and depigmentation bioactivities $[16,19,21]$. Here, we further confirmed the antioxidant and anti-inflammatory effects of 8-HD. 8-HD suppresses the inflammatory responses triggered by different TLR ligands (Figure 3a). We explored the regulatory mechanisms of 8-HD, specifically in terms of the NF- $\mathrm{KB}$ and AP-1 inflammatory signaling pathways. 8-HD downregulates c-Fos transcriptional activity (Figure 4b,c). TAK1 was revealed as the target protein of 8-HD (Figure $5 \mathrm{c}, \mathrm{d}$ ).

The antioxidant effects of 8-HD were evaluated by various methods. Using the Fenton system, the xanthine oxidase system, and FRAP assays, G. Rimbach et al., and JS Park et al. observed that 8-HD scavenges hydroxyl radicals and superoxide, and reduces $\mathrm{Fe}^{3+}$ to $\mathrm{Fe}^{2+}[17,19]$. We also confirmed the antioxidant effects of 8-HD using DPPH and ABTS assays. We observed that 8-HD significantly scavenges free radicals (Figure 2a,b). Moreover, we proved that 8-HD reduces cell-mediated radical production $[17,19]$. In fact, 8 -HD has a potent ability to decrease various kinds of free radicals. It is worth noting that 8-HD is absorbed well during oral administration, showing antioxidant effects in vivo [18]. For these reasons, 8-HD has the potential to be used in drugs and health supplements.

8-HD suppresses NO production triggered by LPS (a TLR4 ligand), poly[I:C] (a TLR3 ligand), and PGN (a TLR2 ligand) (Figure 3b). In TLR4-induced inflammatory responses, 8-HD downregulates pro-inflammatory genes (e.g., iNOS, COX-2, and TNF- $\alpha$ ) and modulates pro-inflammatory signaling pathways (Figures 3 and 4). We speculate that 8-HD would regulate other TLR-induced inflammatory responses, given that there are known shared TLR signaling pathways $[25,26]$. The inhibitory effect of 
8-HD on various TLR pathways could protect against the harmful side effects of inflammation during bacterial and viral infections.

We determined that 8-HD regulates TAK1 activity. Consequently, the transcriptional activities of the MAPKs and AP-1 are blocked (Figure 4c,d). In the case of NF-kB signaling, 8-HD inhibited the transcriptional activities of p65 and p50 (Figure $4 \mathrm{~b}$ ), but we did not observe a change in the

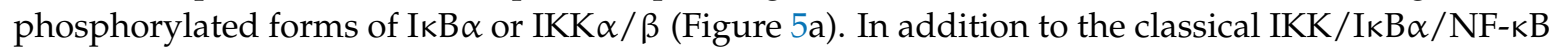
pathway, alternative pathways have been proposed-MAPK cascades could regulate the activation of NF- $\mathrm{KB}$, or other kinases could phosphorylate the NF- $\mathrm{kB}$ subunits. ERK could act upstream of NF- $\mathrm{KB}$, regulating its DNA-binding affinity. It is known that JNK and p38 are involved in cytoplasmic NF- $\mathrm{KB}$ activation and control its activity in the nucleus $[27,28]$. This suggests that $8-\mathrm{HD}$ could regulate the transcriptional activation of NF- $\mathrm{KB}$ and AP-1 by inhibiting TAK1 and/or the MAPKs, as summarized in Figure 6. Apart from the IKKs, there are reports of other kinases that phosphorylate NF-kB. For example, p50 could be phosphorylated by protein kinase A (PKA) or Chk1, affecting its DNA-binding affinity. In the case of p65, GSK3 $\beta$ can phosphorylate the serine at position 468 [29]. The ability of 8-HD to inhibit the activities of these kinases should be addressed in future studies. Nonetheless, it is expected that the inhibitory activity of 8-HD on NF- $\mathrm{kB}$ activity is marginal, since the phosphorylation and degradation of $\mathrm{I} \kappa \mathrm{B} \alpha$ are major pathways to activate NF- $\mathrm{kB}$. Therefore, related points will be further studied to clarify this issue.

The industrial development of natural products is currently receiving much attention. Natural products have traditionally been a source of new drugs [30]. For example, eupatilin (sold as Stillen ${ }^{\circledR}$, a $95 \%$ ethanol extract of Artemisia asiatica Nakai) is widely prescribed for gastritis and peptic ulcers in Korea [31,32]. In addition, the demand for natural and eco-friendly cosmetics is increasing [33,34]. Cosmetic ingredients with anti-inflammatory and antioxidant effects have been shown to reduce irritation $[35,36]$. Researchers have, in fact, tried to develop natural products for use across many industries [34,37,38]. In light of this trend, it is worth noting that 8-HD originates from soybeans. Like soybeans, 8 -HD has potent antioxidant and anti-inflammatory effects. Used synthetically, 8-HD has the potential to be incorporated into many new products, including drugs, cosmetics, and health supplements. In addition, since our team has focused on its development as an immunomodulator targeted at skin inflammation, it is expected that this strategy will overcome various limits caused by liver metabolism and marginal in vivo absorption. Therefore, related studies regarding the pharmacokinetic and pharmacodynamics properties of 8-HD under topical and oral administration conditions will continuous investigate this possibility.

\section{Materials and Methods}

\subsection{Biochemical Reagents}

8-hydroxydaidzein (8-HD) was purchased from INDOFINE Chemical Company, Inc. (Hillsborough, NJ, USA). RAW264.7 cells (a BALB/c-derived murine macrophage cell line, No. TIB-71) and HEK293T cells (a human embryonic kidney cell line, No. CRL-3216) were acquired from the American Type Culture Collection (Rockville, MD, USA). 2,2-diphenyl-1-picrylhydrazyl (DPPH), 2,2'-azino-bis(3-ethylbenzothiazoline-6-sulphonic acid) diammonium salt (ABTS), ascorbic acid, NG-nitro-L-arginine methyl ester (L-NAME), polyethylenimine (PEI), lipopolysaccharide (LPS, Escherichia coli 0111:B4), and peptidoglycan (PGN) were obtained from Sigma Chemical Co. (St. Louis, MO, USA). Poly[I:C] was purchased from Calbiochem (La Jolla, CA, USA). 3-(4,5-dimethylthiazol-2-yl)-2,5-diphenyltetrazolium bromide (MTT) was purchased from Amresco (Solon, OH, USA). Fetal bovine serum (FBS) was purchased from Biotechnics Research (Lake Forest, CA, USA). RPMI1640 and DMEM were obtained from Hyclone (Grand Island, NY, USA). Antibodies against the total and phosphorylated forms of p65, p50, IKB $\alpha, \operatorname{IKK} \alpha / \beta$, ERK, JNK, p38, MEK1/2, MKK4, MKK7, TAK1, HA, and $\beta$-actin were purchased from Cell Signaling (Beverly, MA, USA). 


\subsection{Cell Culture}

RAW264.7 cells were cultured in RPMI1640 supplemented with 10\% heat-inactivated FBS and $1 \%$ penicillin-streptomycin. HEK293T cells were cultured in DMEM with 5\% heat-inactivated FBS and $1 \%$ penicillin-streptomycin. All cells were incubated at $37^{\circ} \mathrm{C}$ in a $5 \% \mathrm{CO}_{2}$ humidified incubator.

\subsection{DPPH Assays}

DPPH decolorimetric assays were performed to examine the scavenging effect of 8-HD [39,40]. A mixture of 8-HD $(0-50 \mu \mathrm{M})$ and $250 \mu \mathrm{M}$ DPPH was incubated at $37^{\circ} \mathrm{C}$ for $30 \mathrm{~min}$. Ascorbic acid $(500 \mu \mathrm{M})$ was used as a positive control. After incubation, the absorbance at $517 \mathrm{~nm}$ of each sample was measured by spectrophotometry. The DPPH scavenging effect was expressed as the percent inhibition:

$$
\text { DPPH scavenging effect }(\%)=\left[\left(\mathrm{A}_{0}-\mathrm{A}_{1}\right) / \mathrm{A}_{0}\right] \times 100
$$

where $\mathrm{A}_{0}$ is the absorbance of $\mathrm{DPPH}$, and $\mathrm{A}_{1}$ is the absorbance of the sample.

\subsection{ABTS Assays}

ABTS scavenging assays were performed with modifications [41]. A mixture of 7.4 mM ABTS and $2.4 \mathrm{mM}$ potassium persulfate (at a ratio of 1:1) was incubated at room temperature overnight to generate ABTS radical cations (ABTS $\bullet$ ). Solutions of 8-HD and ABTS were loaded into 96-well plates at a ratio of 1:1. Ascorbic acid $(50 \mu \mathrm{M})$ was used as a positive control. After 30 min of incubation at $37^{\circ} \mathrm{C}$, the absorbance of each fraction was measured at $730 \mathrm{~nm}$. The ABTS scavenging effect was expressed as a percentage:

$$
\text { ABTS scavenging effect }(\%)=\left[\left(\mathrm{A}_{0}-\mathrm{A}_{1}\right) / \mathrm{A}_{0}\right] \times 100
$$

where $A_{0}$ is the absorbance of ABTS, and $A_{1}$ is the absorbance of the sample.

\subsection{NO Production and Griess Assays}

RAW264.7 cells $\left(1 \times 10^{6}\right.$ cells $\left./ \mathrm{mL}\right)$ were seeded in 96-well plates and incubated overnight. Cells were pre-treated with 8-HD $(0-50 \mu \mathrm{M})$ or L-NAME $(0-1000 \mu \mathrm{M})$ for $30 \mathrm{~min}$, and then LPS $(1 \mu \mathrm{g} / \mathrm{mL})$ was added for $24 \mathrm{~h}$. NO production was determined using Griess reagent, as previously reported $[39,42]$.

\subsection{Cell Viability Assays}

RAW264.7 cells $\left(1 \times 10^{6}\right.$ cells $\left./ \mathrm{mL}\right)$, HEK293 cells $\left(5 \times 10^{5}\right.$ cells $\left./ \mathrm{mL}\right)$, and HaCaT cells $\left(5 \times 10^{5}\right.$ cells $\left./ \mathrm{mL}\right)$ were plated in 96-well plates. Cells were treated with 8 -HD $(0-50 \mu \mathrm{M})$ for $24 \mathrm{~h}$, and MTT solution was then added for $3 \mathrm{~h}$. Cytotoxicity was measured by conventional MTT assay.

\subsection{Preparation of $m R N A$ and Semi-Quantitative PCR}

To quantify the expression of pro-inflammatory cytokines, RAW264.7 cells were pre-treated with 8-HD for $30 \mathrm{~min}$. Cells were then exposed to LPS for $6 \mathrm{~h}$. Total RNA was isolated with TRIzol reagent according to the manufacturer's instructions. Semi-quantitative PCR was conducted as previously described [43].

\subsection{Plasmid Transfections}

HEK293T cells $\left(3 \times 10^{5}\right.$ cells $\left./ \mathrm{mL}\right)$ were seeded in 24-well plates. HA-TAK1 plasmids were transfected into HEK293T cells using PEI. 


\subsection{Preparation of Whole Cell Lysates and Immunoblotting}

Cells were washed with PBS and collected. Cells were centrifuged at 12,000 rpm for $5 \mathrm{~min}$ at $4{ }^{\circ} \mathrm{C}$. Cells were lysed with lysis buffer $(20 \mathrm{mM}$ Tris- $\mathrm{HCl}, \mathrm{pH} 7.4 ; 2 \mathrm{mM}$ ethyleneglycotetraacetic acid (EDTA); 2 mM ethyleneglycotetraacetic acid (EGTA); $1 \mathrm{mM} \mathrm{DTT;} 50 \mathrm{mM} \beta$-glycerol phosphate; $0.1 \mathrm{mM}$ sodium vanadate; $1.6 \mathrm{mM}$ pervanadate; $1 \%$ Triton X-100; $10 \%$ glycerol; $10 \mu \mathrm{g} / \mathrm{mL}$ aprotinin; $10 \mu \mathrm{g} / \mathrm{mL}$ pepstatin; $1 \mathrm{mM}$ benzamide; and $2 \mathrm{mM}$ PMSF). Protein lysates were pelleted by centrifugation $\left(12,000 \mathrm{rpm}, 5 \mathrm{~min}, 4^{\circ} \mathrm{C}\right)$. Supernatants were used for Western blot analyses. The phosphorylated and total forms of p65, p50, IKB $\alpha$, IKK $\alpha / \beta$, ERK, JNK, p38, MEK1/2, MKK4, MKK7, TAK1, HA, and $\beta$-actin were used [44].

\subsection{Statistical Analyses}

The results were analyzed using an ANOVA/Scheffe's post hoc test or the Kruskal-Wallis/Mann-Whitney tests. A $p$-value $<0.05$ was considered statistically significant. All of the statistical tests were carried out using the computer program SPSS (SPSS Inc., Chicago, IL, USA).

Author Contributions: E.K., Y.-G.K., J.L., D.K. and J.Y.C. conceived and designed the experiments; E.K. and Y.-G.K. performed the experiments; E.K., Y.-J.K., T.R.L., J.H.K., J.L., D.K. and J.Y.C. analyzed the data; E.K., J.L., D.K. and J.Y.C. wrote the paper.

Funding: This research was supported by the Basic Science Research Program through the National Research Foundation of Korea (NRF) funded by the Ministry of Education (2017R1A6A1A03015642), Republic of Korea.

Conflicts of Interest: The authors declare no conflict of interest.

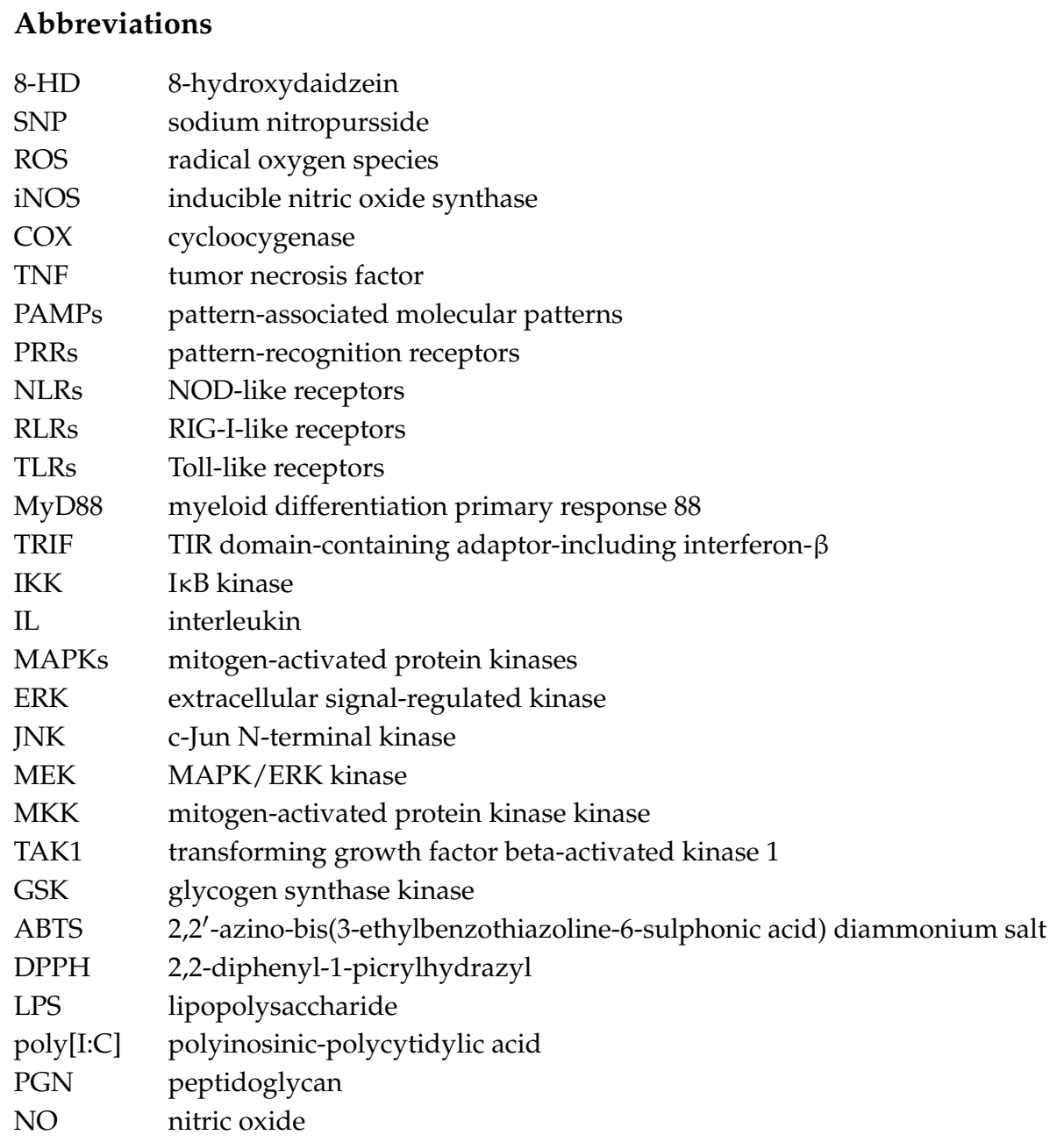




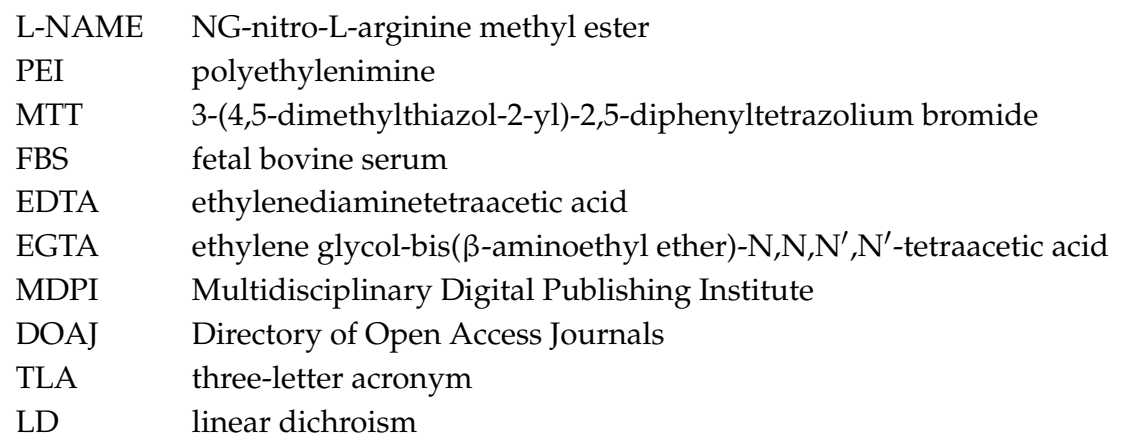

\section{References}

1. Mogensen, T.H. Pathogen recognition and inflammatory signaling in innate immune defenses. Clin. Microbiol. Rev. 2009, 22, 240-273. [CrossRef] [PubMed]

2. Patel, H.; Shaw, S.G.; Shi-Wen, X.; Abraham, D.; Baker, D.M.; Tsui, J. Toll-like receptors in ischaemia and its potential role in the pathophysiology of muscle damage in critical limb ischaemia. Cardiol. Res. Pract. 2012, 2012, 121237. [CrossRef] [PubMed]

3. Kawai, T.; Akira, S. The roles of TLRs, RLRs and NLRs in pathogen recognition. Int. Immunol. 2009, 21, 317-337. [CrossRef] [PubMed]

4. Akira, S.; Takeda, K. Toll-like receptor signalling. Nat. Rev. Immunol. 2004, 4, 499-511. [CrossRef] [PubMed]

5. Takeda, K.; Kaisho, T.; Akira, S. Toll-like receptors. Ann. Rev. Immunol. 2003, 21, 335-376. [CrossRef] [PubMed]

6. Bowie, A.; O'Neill, L.A. The interleukin-1 receptor/Toll-like receptor superfamily: Signal generators for pro-inflammatory interleukins and microbial products. J. Leukoc. Biol. 2000, 67, 508-514. [CrossRef] [PubMed]

7. Gerer, K.F.; Erdmann, M.; Hadrup, S.R.; Lyngaa, R.; Martin, L.M.; Voll, R.E.; Schuler-Thurner, B.; Schuler, G.; Schaft, N.; Hoyer, S.; et al. Preclinical evaluation of NF-kappaB-triggered dendritic cells expressing the viral oncogenic driver of Merkel cell carcinoma for therapeutic vaccination. Ther. Adv. Med. Oncol. 2017, 9, 451-464. [CrossRef] [PubMed]

8. Lawrence, T. The nuclear factor NF-кB pathway in inflammation. Cold Spring Harb. Perspect. Biol. 2009, 1, a001651. [CrossRef] [PubMed]

9. Karin, M.; Ben-Neriah, Y. Phosphorylation meets ubiquitination: The control of NF- $\mathrm{B}$ activity. Ann. Rev. Immunol. 2000, 18, 621-663. [CrossRef] [PubMed]

10. Kawai, T.; Akira, S. TLR signaling. Cell Death Differ. 2006, 13, 816. [CrossRef] [PubMed]

11. Foletta, V.C.; Segal, D.H.; Cohen, D.R. Transcriptional regulation in the immune system: All roads lead to AP-1. J. Leukoc. Biol. 1998, 63, 139-152. [CrossRef] [PubMed]

12. Hossen, M.J.; Kim, S.C.; Son, Y.-J.; Baek, K.-S.; Kim, E.; Yang, W.S.; Jeong, D.; Park, J.G.; Kim, H.G.; Chung, W.-J. AP-1-targeting anti-inflammatory activity of the methanolic extract of Persicaria chinensis. Evid. Based Complement. Altern. Med. 2015, 2015, 608126.

13. Kaufman, P.B.; Duke, J.A.; Brielmann, H.; Boik, J.; Hoyt, J.E. A comparative survey of leguminous plants as sources of the isoflavones, genistein and daidzein: Implications for human nutrition and health. J. Altern. Complement. Med. 1997, 3, 7-12. [CrossRef] [PubMed]

14. Seo, M.-H.; Kim, B.-N.; Kim, K.-R.; Lee, K.W.; Lee, C.-H.; Oh, D.-K. Production of 8-hydroxydaidzein from soybean extract by Aspergillus oryzae KACC 40247. Biosci. Biotechnol. Biochem. 2013, 77, 1245-1250. [CrossRef] [PubMed]

15. Chiang, C.-M.; Ding, H.-Y.; Tsai, Y.-T.; Chang, T.-S. Production of two novel methoxy-isoflavones from biotransformation of 8-hydroxydaidzein by recombinant Escherichia coli expressing O-methyltransferase SpOMT2884 from Streptomyces peucetius. Int. J. Mol. Sci. 2015, 16, 27816-27823. [CrossRef] [PubMed]

16. Fujita, T.; Funako, T.; Hayashi, H. 8-Hydroxydaidzein, an aldose reductase inhibitor from okara fermented with Aspergillus sp. HK-388. Biosci. Biotechnol. Biochem. 2004, 68, 1588-1590. [CrossRef] [PubMed] 
17. Rimbach, G.; De Pascual-Teresa, S.; Ewins, B.; Matsugo, S.; Uchida, Y.; Minihane, A.; Turner, R.; Vafei Adou, K.; Weinberg, P. Antioxidant and free radical scavenging activity of isoflavone metabolites. Xenobiotica 2003, 33, 913-925. [CrossRef] [PubMed]

18. Esaki, H.; Shirasaki, T.; Yamashita, K.; Nakamura, Y.; Kawakishi, S.; Osawa, T. Absorption and excretion of the 8-hydroxydaidzein in rats after oral administration and its antioxidant effect. J. Nutr. Sci. Vitaminol. 2005, 51, 80-86. [CrossRef] [PubMed]

19. Park, J.-S.; Park, H.Y.; Kim, D.H.; Kim, D.H.; Kim, H.K. ortho-Dihydroxyisoflavone derivatives from aged Doenjang (Korean fermented soypaste) and its radical scavenging activity. Bioorg. Med. Chem. Lett. 2008, 18, 5006-5009. [CrossRef] [PubMed]

20. Wu, S.-C.; Chang, C.-W.; Lin, C.-W.; Hsu, Y.-C. Production of 8-hydroxydaidzein polyphenol using biotransformation by Aspergillus oryzae. Food Sci. Technol. Res. 2015, 21, 557-562. [CrossRef]

21. Park, J.-S.; Kim, D.H.; Lee, J.K.; Lee, J.Y.; Kim, D.H.; Kim, H.K.; Lee, H.-J.; Kim, H.C. Natural ortho-dihydroxyisoflavone derivatives from aged Korean fermented soybean paste as potent tyrosinase and melanin formation inhibitors. Bioorg. Med. Chem. Lett. 2010, 20, 1162-1164. [CrossRef] [PubMed]

22. Oeckinghaus, A.; Ghosh, S. The NF-кB family of transcription factors and its regulation. Cold Spring Harb. Perspect. Biol. 2009, 1, a000034. [CrossRef] [PubMed]

23. Corrigan, C.J.; Loke, T.-K. Clinical and molecular aspects of glucocorticoid resistant asthma. Ther. Clin. Risk Manag. 2007, 3, 771-787. [PubMed]

24. Tas, S.W.; Maracle, C.X.; Balogh, E.; Szekanecz, Z. Targeting of proangiogenic signalling pathways in chronic inflammation. Nat. Rev. Rheumatol. 2016, 12, 111-122. [CrossRef] [PubMed]

25. Zhu, J.; Mohan, C. Toll-like receptor signaling pathways-Therapeutic opportunities. Mediat. Inflamm. 2010, 2010, 781235. [CrossRef] [PubMed]

26. Qian, C.; Cao, X. Regulation of Toll-like receptor signaling pathways in innate immune responses. Ann N. Y. Acad. Sci. 2013, 1283, 67-74. [CrossRef] [PubMed]

27. Dhawan, P.; Richmond, A. A novel NF- $\kappa B-i n d u c i n g ~ k i n a s e-M A P K$ signaling pathway up-regulates NF- $\mathrm{kB}$ activity in melanoma cells. J. Biol. Chem. 2002, 277, 7920-7928. [CrossRef] [PubMed]

28. Schulze-Osthoff, K.; Ferrari, D.; Riehemann, K.; Wesselborg, S. Regulation of NF-kB activation by MAP kinase cascades. Immunobiology 1997, 198, 35-49. [CrossRef]

29. Christian, F.; Smith, E.L.; Carmody, R.J. The regulation of NF-kB subunits by phosphorylation. Cells 2016, 5, 12. [CrossRef] [PubMed]

30. Newman, D.J.; Cragg, G.M. Natural products as sources of new drugs from 1981 to 2014. J. Nat. Prod. 2016, 79, 629-661. [CrossRef] [PubMed]

31. Kim, S.H.; Park, J.G.; Hong, Y.D.; Kim, E.; Baik, K.-S.; Yoon, D.H.; Kim, S.; Lee, M.-N.; Rho, H.S.; Shin, S.S. Src/Syk/IRAK1-targeted anti-inflammatory action of Torreya nucifera butanol fraction in lipopolysaccharide-activated RAW264.7 cells. J. Ethnopharmacol. 2016, 188, 167-176. [CrossRef] [PubMed]

32. Ryoo, S.-B.; Oh, H.-K.; Yu, S.A.; Moon, S.H.; Choe, E.K.; Oh, T.Y.; Park, K.J. The effects of eupatilin (stillen $\left.{ }^{\circledR}\right)$ on motility of human lower gastrointestinal tracts. Korean J. Physiol. Pharmacol. 2014, 18, 383-390. [CrossRef] [PubMed]

33. Fonseca-Santos, B.; Corrêa, M.A.; Chorilli, M. Sustainability, natural and organic cosmetics: Consumer, products, efficacy, toxicological and regulatory considerations. Braz. J. Pharm. Sci. 2015, 51, 17-26. [CrossRef]

34. Culasso, B. Natural Cosmetics and Consumer Touchpoints, the Valuable Factors Shaping the Shopping Experience. Master's Thesis, Copenhagen Business School, Frederiksberg, Danmark, 2014.

35. Ghimeray, A.K.; Lee, H.Y.; Kim, Y.H.; Ryu, E.K.; Chang, M.S. Evaluation of antioxidant and anti-inflammatory effect of Rhododendron brachycarpum extract used in skin care product by In Vitro and In Vivo test. Technol. Invest. 2015, 6, 105-111. [CrossRef]

36. Ratz-Łyko, A.; Arct, J.; Pytkowska, K. Moisturizing and antiinflammatory properties of cosmetic formulations containing Centella asiatica extract. Indian J. Pharm. Sci. 2016, 78, 27-33. [CrossRef] [PubMed]

37. Bauer, A.; Brönstrup, M. Industrial natural product chemistry for drug discovery and development. Nat. Prod. Rep. 2014, 31, 35-60. [CrossRef] [PubMed]

38. Amirkia, V.; Heinrich, M. Natural products and drug discovery: A survey of stakeholders in industry and academia. Front. Pharmacol. 2015, 6, 237. [CrossRef] [PubMed] 
39. Hossen, M.J.; Hong, Y.D.; Baek, K.-S.; Yoo, S.; Hong, Y.H.; Kim, J.H.; Lee, J.O.; Kim, D.; Park, J.; Cho, J.Y. In vitro antioxidative and anti-inflammatory effects of the compound K-rich fraction BIOGF1K, prepared from Panax ginseng. J. Ginseng Res. 2017, 41, 43-51. [CrossRef] [PubMed]

40. Blois, M.S. Antioxidant determinations by the use of a stable free radical. Nature 1958, 181, 1199-1200. [CrossRef]

41. Re, R.; Pellegrini, N.; Proteggente, A.; Pannala, A.; Yang, M.; Rice-Evans, C. Antioxidant activity applying an improved ABTS radical cation decolorization assay. Free Radic. Biol. Med. 1999, 26, 1231-1237. [CrossRef]

42. Jung, Y.Y.; Hong, J.T.; Han, S.B.; Park, Y.H.; Son, D.J. Effect of Ixeris dentata Nakai extract on nitric oxide production and prostaglandin E2 generation in LPS-stimulated RAW264. 7 Cells. Immune Netw. 2015, 15, 325-330. [CrossRef] [PubMed]

43. Baek, K.-S.; Yi, Y.-S.; Son, Y.-J.; Yoo, S.; Sung, N.Y.; Kim, Y.; Hong, S.; Aravinthan, A.; Kim, J.-H.; Cho, J.Y. In Vitro and In Vivo anti-inflammatory activities of Korean Red Ginseng-derived components. J. Ginseng Res. 2016, 40, 437-444. [CrossRef] [PubMed]

44. Burnette, W.N. "Western blotting": Electrophoretic transfer of proteins from sodium dodecyl sulfate-polyacrylamide gels to unmodified nitrocellulose and radiographic detection with antibody and radioiodinated protein A. Anal. Biochem. 1981, 112, 195-203. [CrossRef]

(C) 2018 by the authors. Licensee MDPI, Basel, Switzerland. This article is an open access article distributed under the terms and conditions of the Creative Commons Attribution (CC BY) license (http:/ / creativecommons.org/licenses/by/4.0/). 